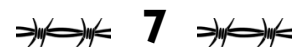

\title{
Silenced border crossings and gendered material flows in southern Albania
}

\author{
Nataša Gregorič Bon
}

My friend Maria and I were sitting on the front porch of the house of the village teacher, Naso, admiring his garden in the spring sun. ${ }^{1}$ Naso was in the kitchen, preparing a welcome drink (qeras/kerasmo ${ }^{2}$ ). Within a few minutes he was in the doorway, holding two glasses of peach juice, which he carefully set on the table in front of us. He smiled and said:

When a man is at home alone he brings the drinks in his hands and not on a tray as his wife would do. This is because he respects his wife. According to the village ways most of the work is done by the woman while her husband is sitting in the coffee-shop (cafeteria), debating with his friends.

Naso paused for a moment, looked into the distance and recited a line from the poem My village (Fshati im) by well-known Albanian poet Andon Zako Çajupi (1990):

Lying in the shade, men

playing, busy chatting,

misfortune cannot strike them,

for they're living off their women. ${ }^{3}$

With a smile on his face he turned to us and added: 'Drink, drink! The juice is delicious; my wife brought it from outside (nga jashtë/apo okso).'4

The juice Maria and I were drinking that afternoon was ordinary peach juice to us, but for Naso it stirred up meanings that were synonymous with wellbeing, modernity and Greece. Despite the fact that the Albanian market offers numerous goods imported from various parts of Europe and Asia, Naso and his fellow villagers boast about the goods their migrant relatives send from the countries of their emigration. This has a historical context to it, since during the years of the communist regime (1945-90) the importation of 'foreign' goods was restricted and crossing the state border strictly forbidden. Many people in Albania, especially those born before the 1990s, consequently value highly goods 
from beyond Albania, referring to them as 'things from outside' (gjëra nga jashte) pragmata apo okso). Thus Naso boasted about the juice he served us, despite the fact that as a 'co-ethnic Greek' he could cross the border officially even before the liberalisation of the visa regime in Albania in 2010. The juice, along with other 'things' (gjëra/pragma) sent from Greece by his migrant wife Frosina, ${ }^{5}$ embody the different regimes of value (Greek vs. Albanian), as well as the geopolitical power of the location from which they originate. The goods that female migrants send to their husbands who stay behind not only reify the meaning of the Albanian-Greek border but also materialise the presence of absent females who live abroad.

The chapter focuses on material flows, which are sporadically sent across the border or given to husbands by female migrants. In contrast to remittances, material flows reflect temporality, materialise interactions between migrants and those who stay behind, and provide a window onto the social, cultural and economic characteristics of the destination countries. I am interested here in the role and meaning of these flows in migration processes and border crossings. The material flows transgress polity borders and social boundaries, reconstruct existing relationships, reaffirm marriage and create material wealth. They stand in as a material presence for absent female migrants, since they materialise the relationships between female migrants and their stay-at-home husbands. They also bring 'migrant worlds' into closer view (Basu and Coleman 2008).

I argue that material flows not only eradicate the spatial distance between Athens and Dhërmi/Drimades but also temporally collapse past, present and future. Following Mazzucato (2010), who conceptualises migrant remittances as part of the reciprocity of social relations, the chapter contends that material flows are entailed in reciprocal exchanges and function as insurance policies, because for female migrants and their husbands they guarantee the future.

Many scholars of migration in Albania concur that male migrants are the first to migrate, with their wives and children joining them afterwards, once their lives in the destination country stabilise (King et al. 2006; King and Vullnetari 2009). This pattern is especially true of northern Albania. However, as Vullnetari (2009) has shown, it is often female migrants who are actively involved in the migration process. They often represent 'the most important pillar for supporting the family migration strategy', for it is they who decide who in the family is going to migrate and who is not (2009). ${ }^{6}$ Following this lead, and in contrast to the majority of scholarly work on migration in Albania and in Europe generally, which largely focuses on remittances in the male domain, this chapter argues that in Dhërmi/Drimades remittances are partly owned and sent by female migrants.

Due to the greater demand for housekeeping services and elderly care-oriented labour, which are often considered to be 'women's work', European migration has become increasingly feminised. In Dhërmi/Drimades, however, female migration is viewed through the dominant patriarchal lens in the village, which effectively 
'silences' women's crossing of the Greek-Albanian border in order to maintain the image that men are still the breadwinners.

Although remittances are returned and managed by female migrants, they paradoxically re-establish the patriarchal ties in the 'home' location. The opening vignette illustrates the power relations that pertain to gender roles within which women are perceived as (re)producing while men enjoy the 'products' of their work. In this perspective, remittances are ambiguous: on the one hand, they provide female migrants with feelings of security and independence, while on the other they re-empower their husbands who stay behind.

My data, gathered during long-term research in Dhërmi/Drimades, document the active role of female migrants who live in Greece (mainly Athens) and send remittances to their husbands who have remained in the village or returned there after retirement. Except in one case, the perspectives on the role and meaning of female migration that I consider were gathered from the women's husbands. In this chapter, remittances are thus described through the gaze of the men who receive and make sense of them. These flows are concretely visible in the gradual construction, rebuilding or refurbishing of village houses, and through receipt of goods such as food, drink and clothes that are regularly sent from Greece.

Following Glick Schiller (2006: 4-5), the chapter shows how transnationalism defines a particular locality by taking into account the wider power relations that seep into it. These power relations are a significant focus of studies of remittances that explore how the sending of things, of money and the overall reciprocal exchange of ideas and care constitute, reaffirm and renew the relationship between migrants and the families left behind (Glick Schiller and Fouron 2001). This brings us to a more complex understanding of the meanings of citizenship and family relations.

Baldassar (2007) argues that remittances and other transnational connections such as 'staying in touch' not only maintain communication between migrants and their relatives but also maintain emotional connections among them. In this way remittances and transnational care influence the meaning of the family. More recent scholarship (Drotbohm 2009) looks at transnational care through the prism of changing power relations and how the meaning of the family is redefined in the process. Drawing on these findings, the chapter considers whether remittances and other material goods returned to Dhërmi/Drimades by female migrants do in fact change existing power relations and whether, instead, they merely reconstitute 'habitual' gender relations.

I begin by introducing the Albanian-Greek border and the 'borderwork' conducted there in order to follow the course of the material flows and the rhythms through which the temporality of the polity border is constituted. I then present the theoretical framework for analysing the material flows before arguing, in the third section, that the reciprocal exchange of 'things' and care binds the migrants and those at home into a shared cyclical time-space. In conclusion, I consider the relationship between linear and cyclical time-space, the first being characteristic 
of borderwork and the second of material flows, though both are grounded in the rhythms that relocate the polity border. 'Border' here is thus shown to be less a line that is fixed and given, than a set of lines that can disappear, reappear, shift and take on different shapes (see Green 2011, 2012).

\section{'Borderwork'}

The Himarë/Himara municipality stretches along the southern Albanian coast and lies $60 \mathrm{~km}$ away from the Albanian-Greek border to the south. The Malet e Vetëtimë ('Thunderbolt Mountains') enclose the area on its northern and north-eastern sides. The area opens up on its south-western side with the mountain of Çika and descends towards the Ionian coast, with the Greek islands of Othonas and Corfu in the distance. The dual name Himarë/Himara identifies the Albanian-Greek border as a 'location of unfinished business and ambivalent attitudes' towards the ethnic, political, historical, cultural and economic differences among the inhabitants (Green 2012: 115). Unlike those living in the areas of the recognised national Greek minority (Saranda, Gjirokastra and Delvina), the bilingual inhabitants of Himarë/Himara are not considered a part of this minority. According to national Greek politics and mainstream Greek public opinion, they are classified as omogheneis or 'co-ethnic Greeks' living in Albania. This status gives them the right to receive Special Cards for Aliens of Greek Descent (Eidiko Deltio Tautotitas Omogeneis), and even before the liberalisation of the visa regime in 2010 allowed them unrestricted passage across the Albanian-Greek and other European Schengen borders. In spite of the fact that in practice most of the villagers do not travel beyond Greece, they frequently emphasise their ability to travel 'freely' to the countries of western Europe. They often use this privilege to differentiate themselves from other citizens of Albania, whose border crossings are still controlled, despite the liberalisation of the visa regime.

Before the beginning of the communist era, marriage in Dhërmi/Drimades tended to be endogamous. ${ }^{7}$ Many endogamous marriages were arranged by the parents of the young couples. According to my conversations with the local people, there were two main reasons for this: one was to keep the land within the village, and the other to maintain and protect their Christian faith, which they felt might be eroded with interfaith marriages in a predominantly Muslim Albania. Under communism the endogamous pattern almost completely vanished but was revived when communism collapsed.

Due to land erosion and the lack of land suitable for cultivation, as well as other wider economic, social and political pressures, people from Himarë/Himara have for many centuries moved back and forth to southern Albania, Epirus, Corfu and Othonas in Greece, and to Venice and Naples in Italy. During my fieldwork between 2004 and 2005, many of those in this area born between 1926 and 1945 told stories about how their ancestors moved across the mountains and over the sea (see Gregorič Bon 2008: 161-181). The stories describing journeys across 
the Thunderbolt Mountains spoke of women undertaking the journey to the fertile valley of Labëria in north-eastern Albania, where the inhabitants were usually described as uncivilised and backward. By contrast, stories of overseas trading relations emphasised male voyages to the Venetian Republic, Naples and Corfu, which were seen as economically and socially prosperous and developed.

These stories are forceful encapsulations of the remembered paths taken by the storytellers' ancestors. Through these accounts, the storytellers reconstruct their own past as well as re-create their present and relate it to the places across the sea and the border with Greece. Understanding this is important for understanding the people and places of this area. Like these stories, the historiography of this area also shows (see Gregorič Bon 2008: 99-159) that the people of contemporary southern Albania, Epirus and Corfu traded amongst themselves in the period before communism and constituted common space between them. These movements brought about a multiplicity of connections between people and places, in contrast to the Ottoman administration and ensuing political divisions (the formation of nation-states) which encouraged differentiation and inequality. Nonetheless, the significant differences of that period were less to do with the present-day Albanian polity borders founded in 1913, and more to do with the religious differences between Muslims and Orthodox Christians that were introduced with the Ottoman Empire.

The movement of people and things for economic and/or social reasons continued in this period and the polity border was experienced and narrated by these people as the 'road' (to dromo) which 'closed' after 1945 with the establishment of the communist dictatorship. For almost fifty years the Albanian borders were strictly controlled (De Waal 2005: 5-7; Green 2012: 111), which not only prohibited the cross-border movement of people and goods, but also prevented any information about the country from leaking out (Green 2012: 111). Despite the fact that Albania's border marked stark differences between Albania and other countries, these differences rarely mattered in people's daily lives. However, this changed with the collapse of the communist regime in 1990, when the 'road' was (at least for the Greek-speaking Orthodox Christians) 'reopened' and massive migration of Albanians followed (Vullnetari 2007: 32-35).

Scholars of migration estimate that after 1990 more than a quarter of Albania's total population migrated, mainly to Greece and Italy (Bajraba 2000; King and Vullnetari 2009; Vullnetari 2009: 2). Massive migration shattered the meaning of the Albanian-Greek border and introduced differences that were no longer definable on the basis of nation-states, but on the basis of global economy and politics with their capacity to define power and hierarchal structures of places. Within this hierarchical restructuring, some places, states, people and things are considered as belonging to the 'West', and therefore as 'civilised', 'modern' and 'European', while others are labelled as part of the 'Balkans', and hence 'uncivilised' and 'not-yet-modernised'. 
The collapse of communism also influenced migration patterns in the Himarë/ Himara area, where the majority of residents migrated to Greece. In recent years, due to the decollectivisation of agriculture and the restitution of land to former owners, emigrants to Greece began to return to the village. They are reconstructing old houses and building new ones, as well as building tourist facilities along the village coast.

The data gathered by my population census of Dhërmi/Drimades between 2004 and 2005 show that in 15 out of 60 marriages (where at least one or both spouses originate from the village) the wife lives and works in Greece while the man remains behind. In the majority of these cases both spouses used to live in Greece where they migrated after communism. Due to their status as co-ethnic Greeks, they have a right to health and social security in Greece. Following retirement, many men decide to return to Dhërmi/Drimades while their wives, who are still working, remain in Greece. The main reason for their return is the real estate they own in Albania, the lower cost of living and the social position they can attain in their home village. ${ }^{8}$ While these 'translocal marriages' (i.e. where both spouses come from the same village or region but one is working abroad while the other returns to Albania) constitute only 25 per cent of village marriages, the stories of the couples concerned illustrate the migrant worlds of Dhërmi/Drimades.

\section{Material flows}

So far I have suggested that for the inhabitants of Himarë/Himara the rhythms of mobility and enclosure have over time generated multiple meanings of border. Before 1945, the Albanian-Greek border was perceived as the 'road' along which people, things and ideas travelled. After 1945, due to the political direction of the communist leader Enver Hoxha, these movements became subject to a strict prohibition on border crossing. The border or the 'road' was closed for more than four decades, and although the people living on each side were very aware of this political divide, social, economic, monetary and political differences between them did not figure much in their daily lives. But in 1991, after the fall of the communist regime, the polity border again became an important part of their lives and itineraries and represented the material power engendering a 'regime of mobility' (Wang 2004: 352).

There has been a lack of scholarly work on gendered border crossings and/ or gendered emplacement and displacement in Europe, a gap which this chapter addresses by following the flow of things and money across the border that creates ambiguity in gender roles and shifts the border. These border relocations and material flows produce a gendering of time-space, in which the reciprocity of material flows gives rise to two contrasting gendered temporalities: linear time and cyclical time, which are associated with men and women, respectively.

Migrant remittances and material flows to the migrants' country of origin 
represent an important part of global and transnational flows, for they are often the main source of income of particular households and economies in many developing countries (Wong 2006: 355). According to the World Bank, remittances are essential to Albanian households in surmounting their economic difficulties (De Soto et al. 2002: xiv). Between 2004 and 2005, remittances amounted to US\$1,100 million and generated 14 per cent of Albanian gross domestic product (GDP) (Vullnetari and King 2011: 55). In 2009, due to the economic crisis across Europe and the United States, the scale of remittances decreased to 9 per cent of GDP in Albania (2011: 55). Still, in the same period, they were three times greater than the value of foreign exports and covered a relatively large part of the trading deficit (2011: 55).

In Dhërmi/Drimades the material flows are part of reciprocal exchange and constitute affective transnationalism where personal and emotional relations between spouses who are 'separated' by polity borders are forged in a distinct way. They secure the material exchange, renew and maintain social relations and establish the material presence of absent migrants (Cliggett 2003). Through material flows migrants maintain and affirm their sense of belonging to their place of origin. As touched on earlier, the material flows bring the mobility of migrants and material culture together (Basu and Coleman 2008). Movements and migration are 'grounded in objects' (Basu and Coleman 2008: 232) such as food and goods, as well as in language and practices. They are also grounded in relationships that mediate and create contexts of movement as well as pauses, or give rise to temporary or permanent settlements. 'Certain forms of materiality can also provide powerful ways of indexing the status and/or agency of the migrant' (Basu and Coleman 2008: 232). As we shall see, the material flows sent by female migrants not only reify the women's absent presence in Dhërmi/Drimades, but also compensate for this absence; and they both materialise female agency and index their husbands' status.

In the following section I examine husbands' narratives about their absent wives to show how the continuity of material flows transcends the spatio-temporal differences between Greece and Albania, improving the economic and social position of female migrants' husbands and ensuring the (common) future of the married couple.

\section{Present in their absence}

\section{Frosina}

On that sunny afternoon when Maria and I were talking with Naso, his wife's absence was experienced not only through his way of offering the drink or through the drink itself (juice from Greece), but also through his narrative. In our many discussions, Naso rarely mentioned his wife Frosina, who was still living and working in Athens. This conspicuous silence can be attributed to a society still dominated by masculine mores where, as in Çajupi's poem, the majority of work is effectively 
done by women but the 'fruits' of that labour are mostly enjoyed by the husbands without giving due recognition to the contribution of their wives.

A few years after the fall of communism, Naso and Frosina - whose marriage was arranged by their parents - migrated to Athens with their children. As they both originate from one of the villages of the Himarë/Himara area and are entitled to the Special Cards for Aliens of Greek Descent, they did not have trouble finding a job there. But despite their Albanian university degrees, Naso and his wife sought jobs as manual workers. Naso, who had been a history and philology teacher, worked in the construction industry, while Frosina, who had been a geography teacher, worked as a cleaning lady. In 2003, when Naso lost his job, he returned to Dhërmi/ Drimades, where he and Frosina built a house on the land that Frosina had inherited from her father. Their sons, who remained in Greece like their mother, sporadically send money to Naso to pay for the new house. Throughout most of the year Frosina stays in Greece and visits Dhërmi/Drimades only two or three times a year, for Christmas, Easter and the summer holidays.

Naso often talked to me about building his house, work on which began in 2002 . Yet only when explicitly asked did he mention Frosina's involvement in the construction and furnishing of their house, despite her regular financial contributions. ${ }^{10}$ Although, as we saw earlier, 25 per cent of marriages in the village are translocal, the absence of migrant wives is rarely mentioned or openly discussed. Naso often said that he 'felt' his wife's presence in his everyday life, due to regular phone calls and the receipt of things she sent him. But in other respects her contributions went unremarked, like those of other migrant village women. Housekeeping, usually the domain of women, is now carried out by the men, sometimes with help from relatives or with hired help, while the material flows that contribute to house-making and are usually the domain of men are delivered by the migrant women. However, this reversal of gender roles is silenced. Since 'house-making' is a culturally gendered activity, the social credit for 'making' a house is attributed to the man and only rarely to his wife.

In 2002, Naso and Frosina spent their savings from working in Greece to build the foundations and basic structure of the house. A year later Naso retired and returned to the village where he hired labourers to build the first floor and three small rooms. Naso himself painted and furnished one of the rooms where he installed a small kitchen, a bed and a table that Frosina had bought in Athens. When Frosina returned to the village for her winter holidays they hired workers who tiled the bathroom and put in a washbasin. They paid them partly from Frosina's savings and partly from Naso's pension. After the holidays, Frosina returned to Athens where she lived in a one-room rented apartment. When relatives return to the village, Frosina always sends with them money for the house and food for Naso (stuffed peppers, meat, cheese, vegetable pies, tinned food, biscuits, beer, coffee and juice). Sometimes she even sends small items of furniture. The couple were planning to furnish one of the larger rooms in their new house when 
Frosina retired, using the remaining furniture from her apartment in Athens. Naso explained that they are very attached to this furniture, which was bought gradually with savings when they were both living in Greece. It represents the life they had together in Athens, and their success and well-being which they had established gradually. ${ }^{11}$ As Basu and Coleman (2008: 317) might say, the very materiality of the furniture evokes and embodies their shared migratory experiences in Greece, while in the meantime Frosina's regular food parcels represent the materiality of her migration.

The 'presence' of absent female migrants is entailed not only in things such as goods and food but also through their mobile phone calls and their constant care for their husbands. As Dhërmi/Drimades is in the vicinity of Corfu, it is within reach of Greek mobile phone networks, enabling Naso and Frosina to talk inexpensively at least once a day. Like Naso, several villagers with relatives in Greece own two phones, one connected to the Albanian network and the other to the Greek one. Because Greece and Albania are in different time zones, the mobile phones connected to the Greek network are set to Greek time, which is one hour ahead of Albania.

During these phone calls, Frosina would ask Naso if he was eating properly and how the house was progressing. Such questions made them feel connected. When I asked Naso if he missed his wife, he explained that he did not, because they talked every day on the phone and regularly sent 'things' to each other: 'Yesterday my cousin, who lives in Athens too, brought me stuffed pepper that she sent through him and some money to pay the workers that made the ceilings in one of the rooms.' In contrast to many other migrant situations, such as Kosovo (Leutloff-Grandits, personal communication), home-made food in Dhërmi/Drimades travels in both directions.

Even though these material flows are instrumental rather than emotional, they are a medium through which the couple stays in touch and maintains connections. The rhythm of material flows is reciprocal and Naso in turn sends Frosina olive oil, olives, oranges and mandarins via their relatives. Such reciprocity is typical between geographically distant couples and a common means to sustain a 'connection', which Drotbohm (2009: 144) suggests is a less emotional and more technical way of keeping in touch than is maintaining 'relations', which has an implication of obligation and responsibility towards those who stay behind.

Despite the fact that 'things', such as furniture, food and other goods, cross the border officially, and that the migrants find themselves paying import tax on furniture, there is an all-pervasive sense in their minds that these border crossings, because of their continuity and reciprocity, somehow defy or transcend the polity border between Albania and Greece. This case study also demonstrates how gendered material flows can impact the meaning of the family in which conventional relationships may be reversed. Men return or stay behind and take care of the household, while women become the main breadwinners and live abroad. 


\section{Sofia}

Sofia's husband Ilia, who was born in Dhërmi/Drimades in 1935, told me a rather different story to that told by Naso. Like many other teenagers at the time, Ilia did not see a future in working in the village cooperative and enrolled in the agronomy school in Durres, the coastal city in central Albania. After completing secondary school, he got a job in Tirana as an agronomist and married Sofia. Sofia was also born in Dhërmi/Drimades and moved to the capital after her marriage, which, like Frosina's, was arranged by her parents. She got a job in the bakery. After the fall of the communist regime in 1990, Ilia and Sofia decided to migrate to Greece with their children. First they moved to Ioannina where they settled with relatives, who had migrated there some time earlier. After two years they moved to Athens, where they rented an apartment. Eight years later, when one of their sons married, they moved to his apartment which they bought with their savings. Ilia worked in various manual jobs as a painter or labourer, while Sofia worked as a cleaner in the mornings and in the evenings cared for her grandchildren. In 2000 their children, who by then were 20, 22 and 26, decided to migrate to Washington, DC in the United States, where Ilia's brother was living. He found jobs for them. Ilia was 65 and retired and decided to return to Dhërmi/Drimades. Sofia decided to move with her children to the United States to continue to care for her grandchildren while their parents were at work. When asked about his wife's decision to migrate to the United States, Ilia explained that many villagers live alone while their wives are abroad so such an arrangement is not unusual. Childcare remains a gendered task in south-eastern Europe, and many women choose to remain in their place of migration if their grandchilden have been born there.

By claiming the status of political refugees, Sofia and her children were able to live and work in the United States but unable to return to Albania. Today Sofia lives in Florida together with the family of one of her sons. Occasionally she sends her savings and other goods such as medicine, clothes and electrical appliances to Ilia.

Like Naso, Ilia rarely talked about Sofia. He mentioned her only when he referred to one of the things she sent from the United States. Besides material objects, Sofia also sent money (US\$400-1,000) twice per year. She usually transferred it through the Western Union money transfer. Ilia invested this money in the construction of a new house. At first, Sofia sent letters and photographs almost every month showing their life in the United States, but later wrote only two or three times a year. Ilia and Sofia normally keep in contact through overseas phone calls and talk to each other at least once a week.

When Ilia returned to the village in 2000, he temporarily moved to an old family house inherited by his younger brother. That same year he began building a house on land inherited from his father. With his savings, the pension which he received from the Greek government as a recognised co-ethnic Greek, and with the help of remittances from his wife, Ilia built two storeys of the house and moved in a year later. He consulted Sofia about matters regarding the house architecture and 
interior design. They spoke frequently about this over the phone, as house-making is their investment in their future. They also discussed their son and grandsons now living with Sofia, and Sofia would caringly inquire about Ilia's eating habits, his health and general well-being. As with Frosina and Naso, the flows between Sofia and her husband are reciprocal and when relatives or friends visit Florida, Ilia asks them to take olive oil, olives, raki (brandy) and honey to Sofia and their children.

Ilia soon realised that the house needed constant work and that he was incapable of doing it on his own. He thus decided to invite a young family from northern Albania, recommended to him by one of his friends. Six months later the family moved to the first floor of the house while he settled on the second floor. The family helps him cook and maintain the house. Though a patriarchal tone is still maintained, marital relations between Ilia and Sofia have changed slightly. Due to the lack of physical contact between them, as well as between Ilia and his children, he considers the family whom he employed to care for him to be his second family. ${ }^{12}$

Ilia once remarked to me that it seems unlikely that Sofia will ever return, a topic they never discuss on the phone. Although divorce is increasingly common in Albania, it is mainly among young couples, and older couples still view divorce with disapproval and disgrace. Sofia's return is only an exit strategy in case things turn upside down 'overnight'.

\section{Lambrini}

In contrast to the narratives described above, Lambrini told me herself about her own migratory career. In 1995 she returned to Dhërmi/Drimades from Athens where she had lived and worked for two years. Unlike Frosina and Sofia, Lambrini had lived in the village for most of her life and worked as the manager of the shop that was part of the village cooperative during communism. Her marriage had also been arranged by the couples' parents. Her husband Kosta was a teacher in a neighbouring village and a few years later was appointed as principal of the primary school in Dhërmi/Drimades. After the fall of the regime the cooperative shop was closed down and the government decided to sell it. Lambrini and Kosta had only 500 Leks of savings which was not enough to buy the shop that was valued at 20,000 Leks. Because Lambrini had envisioned her future in this shop, which was, as she noted, part of her life, she decided to find a job in Greece and move there for a couple of years, until she could save enough money to buy it. Kosta could not join her because he still had a job in the village. Lambrini asked her brother, who had been living in Greece since 1991, to find her a well-paid job in Athens. In the early spring of 1993 she left the village and her family and moved to Athens for two years, where she got a job as a caregiver to an elderly lady, living in her house and saving most of her earnings. Lambrini noted how much she missed her husband and children. She could not talk to them every day, as there were no mobile phones at the time. While Lambrini was working in Athens, she returned only at Christmas, and her 19-year-old daughter took care of her father and siblings. She remitted one-quarter 
of her monthly salary via a relative and saved the rest to purchase the shop. Kosta invested Lambrini's remittances in renovating the house, which had been built in the 1970s. When Lambrini returned to the village she bought the shop, which she later refurbished and reopened as a grocery shop. Her plan had been to extend the range of goods on sale and to include agricultural equipment and clothes, which would make the shop more like the one she had managed for the cooperative. Even though Lambrini realised her ambition and is officially the manager of the shop, the villagers refer to it as 'Kosta's shop' or as 'at Kosta's'.

Some years after she returned to the village her children also decided to emigrate. Her son, who had studied theology but not completed the course, later returned to Albania where he married and settled in his parents' house. Her daughters found jobs and started their families in Greece. Whenever they need support, Lambrini visits Athens and stays with them for a couple of weeks. This again illustrates the translocal caring relations that involve border crossing but still unite and reaffirm existing family relations.

\section{Cyclical rhythms}

The material flows initiated by female migrants from Dhërmi/Drimades are reciprocal, for in exchange for the money, furniture, food and care that they contribute, they receive food (such as olives, olive oil, raki) and reassurance from their husbands. Due to the different regimes of value on each side of the border, the things that cross are not seen as imbalanced by those involved. ${ }^{13}$ The seasonal and reciprocal sending and receiving of things generate rhythms that give rise to cyclical notions of time which transcend the materiality of the polity border. The border is thus de-reified by this repeated exchange which collapses the distance between female migrants in Greece and their husbands in Albania and generates a common time-space between them.

This shared time-space works as an insurance policy, reassuring the female migrants that there is a home to return to if and when the time comes. By sending things home to their husbands, Frosina, Sofia and Lambrini invest in a secure future. Material flows are thus part of their mutual relations, rights and obligations, for they create and reaffirm the marriage bond and its entailments. The labour and effort that the three women invest in their material flows similarly ensure that they are never alienated from these flows. Put differently, the furniture and money that the female migrants invest in 'house-making' represent their inalienable wealth that in turn generates male prosperity and social capital. The material flows are like extensions of the female migrants, functioning as a kind of proxy presence in their absence. Their husbands cannot directly manage the labour and effort that their migrant wives invest in the production of material wealth but they can enjoy their care and manage the material wealth (such as money, furniture and food) sent to them. 
The rhythms of material flows arguably silence the ruptures that result from border crossing and the labour of female migrants, and they replicate the existing power relations between husband and wife. Men perceive their wives' crossings of polity borders as non-transformative and even replicative, especially of gender roles. Despite the fact that it is the female migrants who produce the wealth, largely supporting their households, it is the husbands who manage this wealth and maintain more or less intact the patriarchal power relations as a result. The rhythm of material flows thus transgresses both the continuity implicit in remitting wealth earned by women and the discontinuity embodied by their border crossings.

\section{Gendered dimension of time-space}

Compared to female migrants from northern Albania, the migrants from Dhërmi/ Drimades enjoy greater liberty in managing the material wealth earned as migrants. Thus we saw, for example, that Lambrini was able to invest her savings from Greece in the village shop in her natal village. And though Naso, Ilia and Kosta perceive their wives' remittances as part of their marital male prerogative, their wives can still freely manage them and decide when, how and what they will remit. Material flows in Dhërmi/Drimades are ambiguous in so far as husbands conceptualise them as the husband's right and the wife's obligation, while at the same time wives retain the power to manage them themselves as active agents in the migration process.

The stories of Frosina, Sofia and Lambrini disclose their active economic and social role, which in their husbands' narratives and wider village discourse are often muted and implicit. Thus Naso, Ilia and Kosta rarely explicitly referred to the material flows sent from Greece by their wives, an invisibility perpetuated in wider village discourse when, for example, villagers refer to 'Kosta's shop' even when it is Lambrini who manages it.

Most of what Frosina and Sofia remit from Greece is invested in houses that are locally regarded as belonging to their husbands. Ilia and Kosta, and even Naso, who is building the house on the land which his wife inherited from her father, all describe house construction in the first person. "House-making” by Albanian migrants is not only a simple house-building process; it also ensures a constant dwelling and dynamic "proxy" presence for migrants in their community of origin' (Dalakoglou 2010: 761). Despite the fact that women play a central role in the house-making process, their role is hidden from public view because of the wider gendered village discourse.

The narratives outlined above illustrate women's multifaceted absence expressed in the narratives of their husbands: their physical absence from the daily life in the village, social absence from the village's discourse and also the absence of their voices from the present text. Except for Lambrini, the narratives of Frosina and Sofia are presented through their husbands' voices. The role of women is marginal in public life in Dhërmi/Drimades. Frosina, Sofia and Lambrini are only partially 
visible and related to their husbands' homes and their houses. They are always ambiguously positioned between public and private, affinal and kin-group, migrant destination and home, and this generates their relative location. In other words, even though their role as migrants and wives is important and crucial for the survival of their families, their social status and position often remain hidden in village life and discourse.

The male house construction and the female investment in the house ${ }^{14}$ highlight the gendered dimension of time-space. While the male time-space is grounded in the linear production and construction of the house that is visible in public space, the female time-space is grounded in the cyclical reproduction of home and descendants in domestic space. The seasonal and reciprocal flow of things, ideas and people constitutes the rhythm which brings into relationship as well as separates linear and cyclical processes and/or male and female time-space.

\section{Temporality of the border}

I have suggested in this chapter that material flows not only entail remittances but also reify the 'presence' of female migrants in the village through their contribution of money, furniture, food, letters, postcards, photographs and telephone calls. These flows indirectly fulfil their obligations, enabling them to feel that they are caring wives and mothers, so that effectively their physical absence is overcome.

Povrzanović Frykman (2009: 107) argues that 'displacement of people may bring the replacement of objects'. In Dhërmi/Drimades these objects are part of the cyclical and reciprocal exchange between female migrants and their husbands. 'House-making' and care transcend the geographical, physical and emotional distance between migrant wives and stay-at-home husbands, and de-reify the polity border. The rhythm of the women's movements combines apparent opposites: the dynamics of mobility with the enclosure enforced by the border; the emplacement and displacement of people and things; and the linearity of borderwork with the cyclical time-space of material flows. From this perspective, the material flows are a mode of temporalisation that continuously relocates the border, while also materialising the presence of otherwise absent women.

We have seen that material flows reaffirm the relationship between female migrants and their husbands who stay behind. They reassure the woman's position in the social network in her place of origin. In this sense, material flows are active agents of migrant worlds (Dalakoglou 2010). They constitute the common timespace in the same manner that this common time-space constitutes the material flows. Unfinished houses, the village shop, food, furniture and other goods reveal the migrant worlds of Frosina, Sofia and Lambrini. They materialise their life in Greece and their continuous returns to Albania. These migrant worlds not only reflect their lives in emigration but they also translate one time-space (Athens, in the Eastern European Time Zone) to another (Dhërmi/Drimades, in the Central 
European Time Zone) and thereby create new time-spaces (see Basu and Coleman 2008). The latter break the old rhythms, introducing new ones that conjoin linear male time with cyclical female time.

Baldassar (2007) and Drotbohm (2009) contend that remittances and the transnational care of family members have the effect of changing husband-wife relations. While agreeing with this, this chapter further suggests that in Dhërmi/ Drimades the change in marital relations becomes silenced when men manage, control and enjoy the material wealth remitted by their migrant wives. Silencing their wives' absence is thus a male 'strategy' for maintaining the patriarchal village order which appears to leave marital relations unchanged. To return to Çajupi's poem: men are lying in the shade, busy chatting, as they live off their wives' work and care that in turn generates their symbolic wealth.

\section{Acknowledgements}

I thank the people of Dhërmi/Drimades who allowed me to explore their life stories. Earlier versions of this chapter were presented at conferences at the Universities of Berlin (Humboldt) and Tampere and as guest lectures at the Universities of Helsinki and Ljubljana. I am also indebted to the editors for their insightful comments and suggestions and to the Slovenian Research Agency for financial support.

\section{Notes}

1 Maria and Naso are from Dhërmi/Drimades, a Greek- and Albanian-speaking village in the southern Albanian region of Himarë/Himara (the official Albanian/local Greek names, respectively).

2 As the people living in the villages of Himarë/Himara are bilingual, I refer throughout to both the southern Albanian and local Greek dialects.

3 Burrat nën hie, lozin, kuvendojnë, pika që s'u bie, se nga gratë rrojnë! (Çajupi 1990).

4 Meaning 'from Greece' or 'abroad'.

5 Frosina always brings 'things from outside' whenever she returns from Athens. These 'things' can be food such as feta cheese, coffee, cream, biscuits, sweets or items like shoes and clothes, furniture, household appliances and money (€300-500).

6 Vullnetari (2009: 13) argues that the scholarly work on Albanian migration represents females as passive actors in the migratory process. It generally assumes that patrilinearity still represents the core pattern of kinship, especially in northern Albania (Backer 1983; Young 2000). Material flows are therefore mainly associated with men who are usually considered to be the core actors who send, receive and administer the remittances, while women play only a marginal role in this process (King et al. 2006; King and Vullnetari 2009: 28). However, this trend is gradually changing as female migrants from Albania administer their incomes more frequently than in the past and assume more complex roles in supporting migration than is often supposed.

7 After marriage the woman theoretically joins her husband's household and adopts the surname of his patriline. There are a few cases of a man moving after marriage to the 
house or land under the agreement of his wife's father (in 5 of 86 ikoyenia/familje). If a woman is from Dhërmi/Drimades and marries within the village, the villagers often refer to her by her maiden name or by the surname of her husband's family. Although she may adopt the surname of her affinal group, she is never considered as fully belonging to her affines or in-laws. All her life, even after she has had children and become a mother, her in-laws continue to refer to her as nifi/nusja, the bride.

8 Some of these men also return because of lack of work in Greece. They can draw their pensions through a local branch of the Greek bank in Himarë/Himara but may visit Greece for medical treatment if required.

9 According to Wang (2004: 352), passports and visas form 'a regime of mobility that has been specifically designed by the state to control the movement of people'.

10 Since the fall of the pyramid investment schemes in 1997, which ended with an economic crisis and loss of government control over the state, Frosina, like the majority of Albanians, does not trust bank transfers anymore and remits her earnings via returning relatives.

11 Many of the villagers in similar circumstances do the same and equip their house with furniture they had owned as migrants, explaining this in terms of both nostalgia and parsimony.

12 Ilia is not exceptional as there are other cases in the village where elderly men or women (usually widows) are taken care of by a family coming from another part of Albania.

13 The reasons for this pertain to the geopolitical power of 'things' and cross-border currency differentials. Until 2010, when the economic crisis in Greece reached its peak, migrants living in Greece never expected their Albanian relatives to send them clothes, furniture or money. Even in 2014, when many of the migrants have returned, they still consider Greek and other foreign goods to be of 'better quality' than those available in Albania.

14 In Greek and Albanian there is only one word used for the house and home: spiti/shtëpi.

\section{References}

Backer, B. (1983) 'Mother, sister, daughter, wife: the pillars of traditional Albanian patriarchal society', in M. Utas (ed.), Women in Islamic Societies: Social Attitudes and Historical Perspectives. London: Curzon, pp. 48-65.

Bajraba, K. (2000) 'Contemporary patterns in Albanian emigration', South-East Europe Review, 3: 57-64.

Baldassar, L. (2007) 'Transnational families and the provision of moral and emotional support: the relationship between truth and distance', Identities: Global Studies in Culture and Power, 14: 385-409.

Basu, P. and S. Coleman (2008) 'Introduction. Migrant worlds, material cultures', Mobilities, 3:3, 313-330.

Çajupi (1990) Baba-Tomorri. Tirana: Shtëpia Botuese 'Naim Frasheri'.

Cliggett, L. (2003) 'Gift remitting and alliance building in Zambian modernity: old answers to modern problems', American Anthropologist 105:3, 543-552.

Dalakoglou, D. (2010) 'Migrating-remitting-'building'-dwelling: house-making as 'proxy' 
presence in postsocialist Albania', Journal of the Royal Anthropological Institute, 16, 761-777.

De Soto, H., P. Gordon, I. Gedeshi and Z. Sinoimeri (2002) Poverty in Albania: A Qualitative Assessment. World Bank Technical Paper 520. Washington, DC: World Bank.

de Waal, C. (2005) Albania Today: A Portrait of Post-Communist Turbulence London: I.B. Tauris.

Drotbohm, H. (2009) 'Horizons of long-distance intimacies: reciprocity, contribution and disjuncture in Cape Verde', History of the Family, 14: 132-149.

Glick Schiller, N. (2006) 'Introduction: what can transnational studies offer to the analysis of localized conflicts and protests?', Focaal - European Journal of Anthropology, 47: 3-17.

Glick Schiller, N. and G.E. Fouron (2001) Georges Woke up Laughing: Long-Distance Nationalism and the Search for Home. Durham, NC: Duke University Press.

Green, S. (2011) Traces, Tidemarks and Legacies. 110th Annual Meeting, Montreal, QC, Canada, 16-20 November.

Green, S. (2012) 'Replacing Europe', in R. Fardon et al. (eds), The Sage Handbook of Social Anthropology Volume 1. London: Sage.

Gregorič Bon, N. (2008) Prostori neskladij: Etnografija prostora in kraja v Dhërmiju/ Drimadesu, južna Albanija. Ljubljana: Založba ZRC, ZRC SAZU.

King, R., M. Dalipaj and N. Mai (2006) 'Gendering migration and remittances: evidence from London and Northern Albania', Population, Space and Place, 12: 409-434.

King, R. and J. Vullnetari (2009) 'The intersections of gender and generation in Albanian migration, remittances and transnational care', Geografska Annaler: Series B, Human Geography, 9: 19-38.

Mazzucato, V. (2010) 'Reverse remittances in the migration development nexus: two-way flows between Ghana and the Netherlands', Population, Space and Place, doi: 10.1002/ psp.

Povrzanović Frykman, M. (2009) 'Material aspects of transnational social fields: an introduction', Dve Domovini/Two Homelands (Tematski sklop/Thematic Section: Migrants' Transnational Practices. The Movement of People and Objects), 29: 105-114.

Vullnetari, J. (2007) Albanian Migration and Development: State of the Art Review. IMISCOE Working Paper No. 18. http://edoc.bibliothek.uni-halle.de/servlets/ MCRFileNodeServlet/HALCoRe_derivate_00003672/Albanianmigration.pdf. Accessed 2 August 2016.

Vullnetari, J. (2009) Women and Migration in Albania: A View from the Village. Oxford: Blackwell.

Vullnetari, J. and R. King (2011) Remittances, Gender and Development: Albania's Society and Economy in Transition. London: I.B. Tauris.

Young, A. (2000) Women who Become Men: Albanian Sworn Virgins. Oxford: Berg.

Wang, H. (2004) 'Regulating transnational flows of people: an institutional analysis of passports and visas as a regime of mobility', Identities, 11(3): 351-376.

Wong, M. (2006) 'The gendered politics of remittances in Ghanaian transnational families', Economic Geography, 82(4): 355-381. 